\title{
傾聴 (和)の思想の起源は『詩経』の音楽の唱和である
}

\author{
浜村 良久 \\ (防衛大学校人間文化学科) \\ 唱和、傾聴、詩経
}

\begin{abstract}
The idea of listening is derived from a chorus of music in The Book of Odes.
Yoshihisa HAMAMURA

(National Defense Academy)

chorus, listening, The Book of Odes
\end{abstract}

これまでの研究において、孔子、顔回は不違 (無批判)の傾 聴を唱え実践する人であったこと（浜村・水野, 2011)、傾聴は 荘周へ伝えられて「和」と呼ばれ、『荘子』の「和而不唱」「心 斎」の思想に結実したことが明らかになった（浜村, 2006, 2009)。しかし、(1)なぜ傾聴を「和」と呼ぶのか、(2)「和」の 起源は何かについては明らかではなかった。そこで本研究で は孔子が学園のテキストとした『詩経』の「和」の用例を検 討し傾聴の「和」の起源を明らかにする（浜村・水野, 2012）。

\section{1. 国風における合唱の「和」の用例（1 例）}

『詩経』鄭風「鋅兮」には「倡うれば予れ女に和さん(も しあなたが私を歌で誘うなら、私もあなたに歌で応えましょ う)」とある。国風の「和す」とは同時に歌い始めることでな く、相手の独唱に応えて自分の歌を和す唱和のことである。 構造的にも国風は発問と応答からなる詩が多く、唱和形式で 歌われていたと考えられる。

\section{2. 雅頌における合奏の「和」の用例（11 例）}

当時の楽師は盲人なので、指揮者の指揮で一斉に合奏はで きず、ある楽器を先行させて他の楽器が和す唱和形式で合奏 したはずである。孔子も「楽」を「始めて作すに拿如たり。 これを従ちて純如たり、曒如たり、繹如たり（合奏は盛り上 がるような金属の打楽器の鳴奏によって始まり、やがて諸楽 器の自由な参加によってかもし出される純粋な調和、次いで 管・弦・打楽などの各パートが代わる代わる独奏し、各種の 音声が相連続して絶えない)」(『論語』八份篇 23 章) と言う。

『詩経』雅頌の「和」は従来、「和らぐ」と解されてきたが、 鳥獣の鳴声や合奏の文脈で用いられているので、「唱和」と解 釈できる。たとえば、小雅「伐木」第 1 章、

伐木丁丁、鳥鳴嚶嚶。出自幽谷、遷于喬木。

嚶其鳴矣、求其友声。相彼鳥矣、猶求友声。

知伊人矣、不求友生。神之聴之、終和且平。

の第 5、6 句では「嚶として其れ鳴く、其の友を求むる声」と いう。鳥は雄が囀って雌を誘い(唱)、雌が応える(和)ので、

「終和」は友を求める声に応じて人や神も「ついに和す」こ とと解釈できる。

また、「和楽」「和奏」「和鳴」も「楽(奏、鳴)を和す」と解 釈できる。たとえば、小雅「鹿鳴」第 3 章、

呦呦鹿鳴、食野之芩。我有嘉賓、鼓瑟鼓琴、鼓瑟鼓琴、

和楽且湛。我有旨酒、以嘉楽嘉賓之心。

の「和楽」は、雌雄の鹿が呦呦と鳴き交わすように、瑟と琴 が「代わる代わる独奏」(八佾篇 23 章)する (鼓瑟鼓琴、鼓瑟 鼓琴)のであるから、「楽を和す」と解釈できる。

\section{3. 雅頌における鈴の音、味の調和の用例（4 例）}

周頌「載見」の「和鈴」は車の鈴、小雅「蓼蕭」の「和鸞」 は馬の鈴で、車馬の動き（唱）に応じて鈴がシャンシャンと 「和す」ため「和鸞」「和鈴」と呼ばれるようになった。 小雅「賓之初笘」の「酒既和旨」、商頌「烈祖」の「亦有和 羍」は酒やスープの美味を言う。料理で五味を調和させ、素
材のよさや味が引き立てあうようにするのを「和える」とい う。このように、『詩経』小雅・頌の「和」の用例も国風と同 様、「唱を前提とする和」として一貫している。

\section{4、音楽の「和」から人間関係の「和」へ}

演奏は直前までの旋律 (唱)を受けて音を和し続けるプロセ スなので、「唱和」は演奏の本質的要素である。孔子の弟子た ちは盲の楽師に師事し、他の楽器の演奏の流れをよく聴き、 自分の音を和していく「和」の精神を学んだ。従来の研究で は「楽」を聴く立場から捉えたので、「和」は状態としての「調 和」とされてきた。しかし「楽」を演奏する立場から捉える と、演奏は己を抑えて他者に聴き、自分の音や声を和す「和」 の実践であることが分かる。演奏による「和」の実践は自己 の修養となる(「楽に成る」泰伯篇 8 章)。これこそが孔子が 詩楽を重視した理由であろう。

「唱を前提とする和」を人間関係に当てはめると、「和」は 単に人に合わせることではなく、「相手にまず気持ちを話させ (唱)、それを大切に受け止めながら、共感と理解の気持ちを 示す(和)」ことになる。「和」は常に相手に「唱」させること を前提としている。このように接してもらえると、人は自分 の分かってほしいことを聴いてもらえた、理解されたと感じ て心が和らぎ、相手に信頼が生じ、場が和やかになる。

孔子は「君子は和して同ぜず、小人は同じて和せず」（子路 篇 23 章) と言う。これを「唱を前提とする和」から捉えると、 君子は相手の話 (唱)を傾聴し共感と理解を示す(和)が、無闇 に同調はしない(不同)。小人はすぐ雷同する(同)が、相手の 心をまず理解し共感しようとしない(不和) と解釈できる。

また、学而篇 12 章に「礼の用は和するを貴しと為す。先王 の道も斯れを美しと為す。小大これに由るも行なはれざる所 あるは、和するを知りて和せんとするも、礼を以てこれを節 せざれば、亦た行なうべからざればなり」と言う。これも「礼」 の効用には様々あるが、我を抑え、人にまず話させて (唱) 傾 聴し、相手に共感と理解を示す(和)ようになれることが最も 素晴らしい効用であると解釈できる。「先王の道」とは『詩経』 である。どんなことでも和を旨とするのがよいが、時にうま くいかないことがあるのは、和が大切だと分かって実行して も、礼で我を抑えない限り我執のため相手に共感を示し続け ることができなくなるからであると解することができる。

以上のように、傾聴の思想の起源は『詩経』の「唱和」で ある。孔子は古来の「詩楽」の根底に「唱和」の思想を見出 し、これを人間関係の傾聴にあてはめ、修養にも役立てよう とした。孔子が弟子の教育に「詩楽」を重視したのは、弟子 たちに「唱和」の思想を実践させるためであったのであろう。

\section{引用文献}

浜村良久, 2006, 中国古典研究, 51, 32-48.

浜村良久, 2009, 比較文化研究, 86, 17-28.

浜村良久 ・水野実, 2011, 新しい漢字漢文教育, 52, 17-26.

浜村良久・水野実, 2012, 東洋の思想と宗教, 29, 20-34. 